\title{
Postmortem blood ferritin concentrations in sudden infant death syndrome
}

\author{
M Worwood, R Raha-Chowdhury, D G Fagan, C A Moore
}

\begin{abstract}
Aims-To confirm the observation of extremely high concentrations of ferritin in postmortem serum samples in sudden infant death syndrome (SIDS); to examine the factors influencing blood ferritin concentrations postmortem; to determine whether or not these high blood ferritin concentrations are characteristic of SIDS. Methods-Postmortem samples of cardiac blood were obtained from 58 full term infants who died of SIDS and 14 full-term infants who died of a variety of other causes. Whole blood and serum ferritin concentrations were determined and compared with age at death, liver iron concentration, serum iron concentration, and
\end{abstract} serum lactate dehydrogenase activity.

Results-The median postmortem blood ferritin concentration for all infants was $18600 \mu \mathrm{g} /$, which is about 200 times the concentration found in the serum of normal, live infants. Serum iron concentrations were high and there was a highly significant correlation between serum ferritin and iron concentrations suggesting that much of the serum iron was contributed by ferritin. There was no significant difference between serum and whole blood ferritin concentrations. $H$ to $\mathrm{L}$ type ferritin ratios were higher in blood from the left than the right ventricle of the heart but the ferritin was always predominantly $L$ type. Blood ferritin concentrations rose rapidly after death but in samples collected at postmortem examination there was a significant correlation with liver iron concentration and an inverse correlation with age. Median values for blood ferritin were higher in SIDS ( $22500 ; n=58)$ than in control cases $(6900 ; n=7)$ dying under one year of age; however, in both groups ferritin concentrations decreased with age.

Conclusions-Release of ferritin into the blood postmortem seems to be characteristic of infants dying before the age of one year rather than characteristic of SIDS. Two factors may cause such ferritin release postmortem: tissue breakdown and the high level of storage iron in cells of the reticuloendothelial system (including endothelial cells lining vessel walls). SIDS occurs when tissue iron concentrations are higher than at any other time of life. It is possible that the ready availability of iron enhances free radical damage which might be implicated in SIDS.

( $f$ Clin Pathol 1995;48:763-767)

Keywords: Sudden infant death syndrome, ferritin, iron.

The peak incidence of the sudden infant death syndrome (SIDS) is between two and four months of age ${ }^{1}$ when mean blood haemoglobin concentrations are lower ${ }^{2}$ than at any other time of life.

We have recently reported that postmortem liver iron concentrations are higher in SIDS than for deaths from other causes, and that there is an inverse correlation with age. ${ }^{3}$ As the normal range for liver iron concentrations in infancy has not yet been established, it is not possible to say that liver iron concentrations in SIDS differ from those in normal healthy infants.

We have also noted extremely high ferritin concentrations in postmortem cardiac blood in SIDS. ${ }^{4}$ This paper reports on postmortem blood ferritin concentrations infants who died of SIDS and who died of other causes, and describes some of the factors which influence postmortem blood ferritin concentrations. Iron is an important factor in oxidative cell damage and may be involved in the final metabolic events in SIDS.

\section{Methods}

Postmortem samples of cardiac blood were obtained from 58 full-term infants (36 weeks gestation or more) who died of SIDS and 14 full-term controls who had died from a variety of causes when aged less than $2 \frac{1}{2}$ years. The cause of death was described as SIDS after full examination by the pathologist at each of the four centres and in accordance with the definition given by Beckwith. ${ }^{5}$ Details of the controls are given in table 1 . For the 23 cases of SIDS and four controls collected in the West Midlands, blood was obtained from both left and right ventricles and serum separated before storage at $-20^{\circ} \mathrm{C}$. In other cases whole blood was collected in EDTA and frozen. In every case a sample of liver was collected and stored frozen. ${ }^{3}$ In 12 cases blood samples were obtained as soon as the infant reached the accident and emergency clinic or even before death (table 2). The maximum time interval between death and this sample was estimated from information provided by parents or hospital staff. 
Table 1 Control subjects (dying when aged between one month and two years)

\begin{tabular}{|c|c|c|c|c|c|}
\hline Patient No. & $\operatorname{Sex}(F / M)$ & $P C A$ (weeks) & Cause of death & Liver iron ( $\mu g / g$ wet wt) & Blood ferritin $(\mu g / l)$ \\
\hline 1 & $\mathbf{M}$ & 40 & Streptococcal septicaemia & 1016 & 91000 \\
\hline 2 & M & 41 & Asphyxia at birth & 261 & 11000 \\
\hline 3 & $\mathrm{~F}$ & 50 & RSV pneumonitis & 284 & 20800 \\
\hline 4 & $M$ & 59 & Intussussception & 220 & 1600 \\
\hline 5 & $\mathrm{M}$ & 65 & RSV pneumonitis and bronchopneumonia & 105 & 6900 \\
\hline 6 & M & 69 & Endocardial fibroelastosis (sudden death) & 258 & 1470 \\
\hline 7 & $\mathbf{M}$ & 74 & $\begin{array}{l}\text { Congenital heart disease, right ventricular } \\
\text { failure }\end{array}$ & 66 & 120 \\
\hline 8 & _ & 105 & Freshwater drowning & 46 & 2200 \\
\hline 9 & $\mathrm{~F}$ & 109 & Viral myocarditis & 57 & $700^{*}$ \\
\hline 10 & $\mathrm{~F}$ & 122 & No satisfactory cause of death & 155 & 3900 \\
\hline 11 & - & 126 & Fractured skull & 26 & 2450 \\
\hline 12 & $\mathbf{M}$ & 138 & Gastroenteritis, gut perforation & 168 & $240^{*}$ \\
\hline 13 & $\mathrm{~F}$ & 140 & Ventricular septal defect, influenza A & 54 & 1200 \\
\hline 14 & $\mathrm{M}$ & 144 & Freshwater drowning & 53 & 200 \\
\hline
\end{tabular}

* Serum ferritin. RSV = respiratory syncytial virus.

Samples were also obtained at the full postmortem examination and the interval between the two samples was recorded. Samples were not included if the infant had received blood transfusions, except for one case in the study of changes in ferritin concentration after death (table 2).

Serum was obtained for ferritin estimation from 14 live infants age between one and six months undergoing venepuncture before surgery or for other investigations.

Samples were collected from four centres in the United Kingdom: the West Midlands (Wolverhampton, Birmingham, Stafford), Cardiff, Nottingham, and Edinburgh. All estimations were performed in Cardiff. Blood samples were stored at $-20^{\circ} \mathrm{C}$ for up to two years before testing.

\section{ASSAYS}

Liver non-haem iron concentration

The iron content of liver was determined by the method of Torrance and Bothwell, ${ }^{6}$ using ferrozine as the chromogen. Results are expressed as $\mu \mathrm{g}$ iron/g wet weight.

\section{Liver ferritin concentration}

A small piece of liver weighing about $0.05 \mathrm{~g}$ was blotted dry and homogenised in $1 \mathrm{ml} 0.9 \%$ $\mathrm{NaCl}$. The homogenate was centrifuged at $12000 \times g$ for four minutes and diluted in assay buffer before being assayed at a range of dilutions from 1 in 10 to 1 in 10000 by the enzyme linked immunosorbent assay (ELISA) for "L" type ferritin as described later. Results are expressed as $\mu \mathrm{g}$ ferritin/g wet weight.

\section{Blood ferritin concentrations}

Ferritin (L type) was determined by ELISA $^{7}$ using a mouse monoclonal antibody to human spleen ferritin (kindly supplied by $\mathrm{R}$ Henley, Cardiff) as the solid phase antibody, rabbit antiliver ferritin coupled with horseradish peroxidase (Dako, High Wycombe, UK) as the second antibody, and spleen ferritin as the standard. The standard was calibrated against the second international standard for the assay of serum ferritin (reagent 80/578, National Institute for Biological Standards and Control, South Mimms, UK). $\mathrm{H}$ type ferritin was also determined in serum by ELISA with human heart ferritin as standard ${ }^{8}$ and monoclonal antibody to heart ferritin (kindly provided by Dr J Cook, Kansas City, Kansas, USA) for both the solid phase and labelled antibodies. When whole blood was assayed, the sample was diluted with an equal volume of deionised water, frozen (in dry ice) and thawed three times before centrifugation at $12000 \times g$ for three minutes. The supernatants were diluted in assay buffer and assayed at several dilutions.

\section{Lactate dehydrogenase activity}

Lactate dehydrogenase (LDH) activity was determined as described by Elliott and Wilkinson ${ }^{9}$ for the cases where serum was available.

\section{Serum iron concentrations}

These were determined as described by Worwood and Darke. ${ }^{10}$

\section{Statistical analysis}

This was carried out as indicated in the results section using Minitab Statistical Software.

Table 2 Changes in cardiac blood ferritin concentration after death

\begin{tabular}{|c|c|c|c|c|c|c|c|c|}
\hline \multirow[b]{2}{*}{$\begin{array}{l}\text { Patient } \\
\text { No. }\end{array}$} & \multirow[b]{2}{*}{$\begin{array}{l}P C A \\
\text { (weeks) }\end{array}$} & \multirow[b]{2}{*}{$\begin{array}{l}\text { Gestational } \\
\text { age (weeks) }\end{array}$} & \multirow[b]{2}{*}{ Cause of death } & \multicolumn{2}{|l|}{ First sample } & \multicolumn{2}{|c|}{ Second sample } & \multirow[b]{2}{*}{$\begin{array}{l}\text { Liver ferritin concentration } \\
(\mu g / g \text { wet wt) }\end{array}$} \\
\hline & & & & $\begin{array}{l}\text { Estimated time } \\
\text { (h) } \dagger\end{array}$ & $\begin{array}{l}\text { Ferritin } \\
(\mu g / l)\end{array}$ & $\begin{array}{l}\text { Time } \\
(h) \ddagger\end{array}$ & $\begin{array}{l}\text { Ferritin } \\
(\mu g / l)\end{array}$ & \\
\hline 1 & 33 & 29 & (Transfused) & a & 2200 & 11 & 20700 & 302 \\
\hline 2 & 38 & 36 & SIDS & $<5$ & 25000 & 31 & 33200 & - \\
\hline 3 & 40 & 38 & Streptococcal septicaemia & $<2$ & 11400 & 30 & 91000 & 1016 \\
\hline $\begin{array}{l}3 \\
4\end{array}$ & $\begin{array}{l}40 \\
42\end{array}$ & $\begin{array}{l}38 \\
35\end{array}$ & $\begin{array}{l}\text { SIDS } \\
\text { SID }\end{array}$ & $<1$ & 7300 & 32 & 106000 & 421 \\
\hline 5 & 45 & 40 & SIDS & - & $500^{*}$ & 24 & 11000 & - \\
\hline 6 & 46 & 36 & SIDS & $<2$ & 1790 & 25 & 21200 & 159 \\
\hline 7 & 51 & 41 & SIDS & $<1$ & 25000 & 54 & 34500 & 386 \\
\hline 8 & 54 & 36 & RSV pneumonitis, bronchopneumonia & b & 1300 & 42 & 6900 & 98 \\
\hline 9 & 54 & $T+3$ & SIDS & $<1$ & 4350 & 27 & 25400 & - \\
\hline 10 & 58 & 38 & SIDS & $<2$ & 3650 & 6 & 8150 & 152 \\
\hline 11 & 66 & 39 & SIDS & $<8$ & 4930 & 24 & 23400 & 147 \\
\hline 12 & 112 & 35 & Streptococcal septicaemia & $<1$ & 54 & 21 & 76 & 43 \\
\hline
\end{tabular}

* Serum; † estimated time between death and first blood sample (see text); $\ddagger$ time between first blood sample (Accident and Emergency) and second blood sample (postmortem); $a=$ alive on ward; no resuscitation; $b=$ died in Accident and Emergency clinic. 


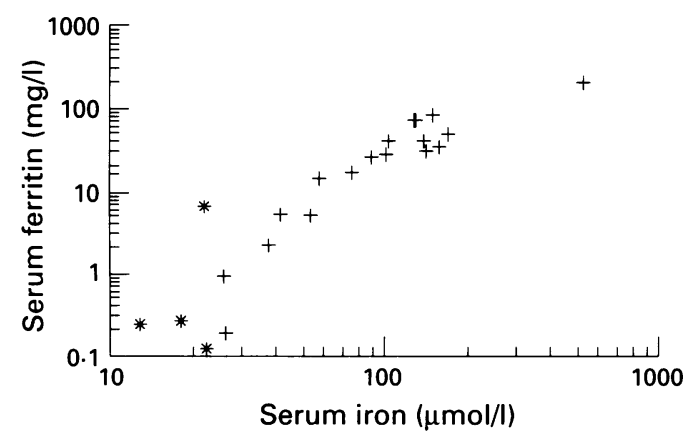

Figure 1 Correlation between serum ferritin and serum iron concentrations in 21 postmortem samples (17 SIDS $(+)$ and four controls (*)). Linear regression analysis for log ferritin against log serum iron concentration shows a highly significant correlation $(r=0.921, p<0.001)$.

\section{Results}

In the 14 live infants age between one and six months serum ferritin concentrations ranged from 20 to $150 \mu \mathrm{g} / \mathrm{l}$, falling within the expected range for this age group. ${ }^{11}$ In postmortem samples the median blood ferritin concentration was $18600 \mu \mathrm{g} / \mathrm{l}(95 \%$ confidence interval (CI) $11200-26000 \mu \mathrm{g} / \mathrm{l}$ ) about 200 times the concentration found in the serum of normal infants aged three months. In cases of SIDS the median blood ferritin concentration was $22500 \mu \mathrm{g} / \mathrm{l}(95 \%$ CI $15600-32000 \mu \mathrm{g} / \mathrm{l})$ significantly higher than the median of $6900 \mu \mathrm{g} / 1$ $(95 \%$ CI $200-20800 \mu \mathrm{g} / \mathrm{l})$ in the non-SIDS cases under 12 months of age $(p=0.049$, two sample Wilcoxon rank sum test). In both groups, however, ferritin concentrations declined with age.

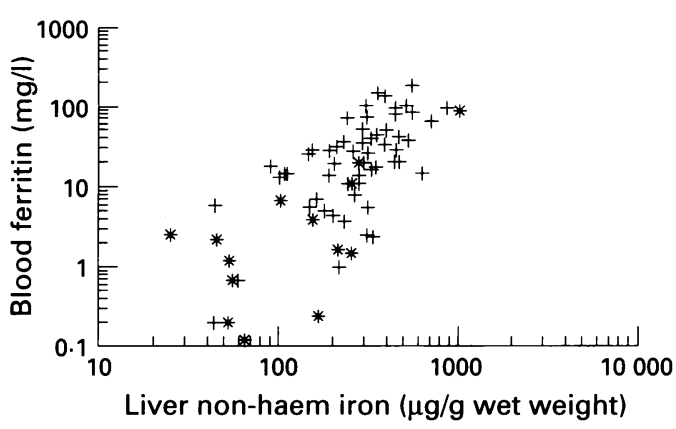

Figure 2 Correlation between blood ferritin and liver non-haem iron concentrations in 58 SIDS (+) and 14 control cases (*). For linear regression analysis the regression equation is $\log _{10}$ (blood ferritin) $=2 \cdot 58+1.57$ $\log _{10}$ (liver iron) $(r=0.698, p<0 \cdot 001)$.

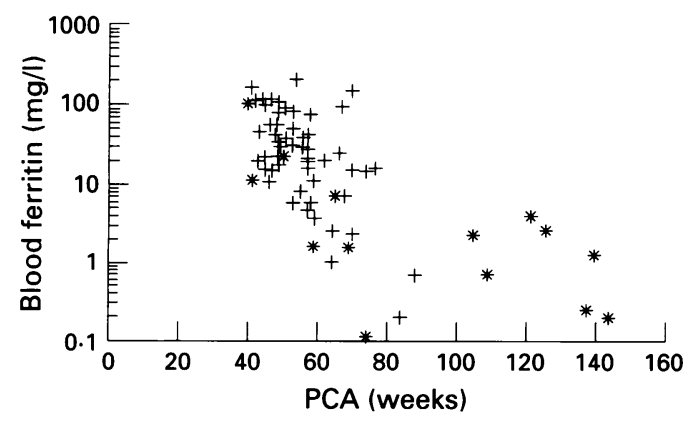

Figure 3 Correlation between blood ferritin concentration and PCA in 58 SIDS ( + ) and 14 control cases (*). The regression equation is $\log _{10}$ (blood ferritin) $=2.45-0.0213$ $P C A(r=-0.680, p<0 \cdot 001)$.
In normal infants aged up to six months the total binding capacity of serum iron increases with age but does not exceed $80 \mu \mathrm{mol} / 1 .^{12}$ In 11 of the 21 postmortem samples examined the serum iron concentration was higher than this and there was a highly significant correlation between plasma ferritin and plasma iron concentrations (fig 1).

In the cases of SIDS there was no significant difference between serum and whole blood ferritin concentrations (Kruskal-Wallis test, $\mathrm{n}=58, \mathrm{H}=0.17, \mathrm{p}=0.677)$, and these concentrations have therefore been combined in the analysis of the data.

Cardiac blood ferritin concentrations correlated with liver iron concentration (fig 2) and inversely correlated with postconceptional age (PCA) (fig 3). Liver iron concentrations also decline with age. ${ }^{3}$ Blood ferritin concentrations were found to rise rapidly after death in a small group of infants for whom samples were available immediately after death as well as at the full postmortem examination (table 2). There was no significant correlation between the increase in ferritin concentration and the time lapse between the two samples or between the final ferritin concentration (either expressed in $\mu \mathrm{g} / 1$ or as a multiple of the first value) and estimated time since death in this group. However, in two cases the ferritin concentration was initially very high and in one older, nonSIDS case both concentrations were very low. The initial values were still considerably higher than the expected value of about $50 \mu \mathrm{g} / 1$ in serum (about $250 \mu \mathrm{g} / \mathrm{l}$ in blood) for a healthy infant aged six months.

Blood ferritin concentrations (transformed as $\log _{10}$ ) were compared with liver iron concentrations and the estimated time interval between death and postmortem examination for all cases, and for cases of SIDS, using multiple linear regression analysis. The time interval was not found to be a significant variable.

In the samples from Wolverhampton we were able to compare blood from the left and right ventricles of the heart in 16 cases of SIDS. Although the mean concentrations in the left $(51000 \mu \mathrm{g} / \mathrm{l})$ and the right $(52000 \mu \mathrm{g} / \mathrm{l})$ ventricles were almost identical, the concentration in the left was less than that in the right in 14 of 16 cases and the paired Student's $t$ test showed that values were significantly lower in the left ventricle $(p<0.01)$. Concentrations were also measured with assays specific for $\mathrm{H}$ and $\mathrm{L}$ type ferritin as described in the methods section. In cardiac muscle the ratio of $\mathrm{H}$ to $\mathrm{L}$ ferritin is in excess of 1 compared with a value of about 0.04 for liver ferritin. ${ }^{13}$ The mean value for the left ventricle samples was 0.097 and for the right $0 \cdot 021$. Using the paired $t$ test this difference was highly significant $(\mathrm{p}=$ 0.003 ). This suggests that a greater proportion of ferritin in the left ventricle may be derived from cardiac muscle than in the right ventricle.

Examination of serum from the left and right ventricles for the isoenzyme distribution of $\mathrm{LDH}^{14}$ revealed a predominantly "liver" pattern $^{15}$ in one pair of samples from a case of SIDS and another pair from a control. There was a highly significant correlation between 
liver iron and liver ferritin concentrations (linear regression analysis $r=0.63, p<0.001$ ) and also between blood and liver ferritin concentrations (linear regression analysis of data transformed to $\log _{10} \mathrm{r}=0.52, \mathrm{p}<0.001$ ).

\section{LACTATE DEHYDROGENASE}

LDH activity in blood was very high in both SIDS and control cases. The mean value in 23 cases of SIDS was $3509 \mu \mathrm{g} / 1$ (range $722-7200 \mu \mathrm{g} / \mathrm{l}$ ) and in five control cases (PCA 44-174 weeks) was $2735 \mu \mathrm{g} / \mathrm{l}(559-4774 \mu \mathrm{g} / \mathrm{l})$. This suggests a similar degree of cellular damage although haemolysis may also have contributed to high serum activities. There were no significant correlations between LDH activity and PCA, liver iron concentration, or blood ferritin concentration.

\section{Discussion}

This is the first reported study of postmortem blood ferritin concentrations in infants. In life the assay of serum ferritin has considerable clinical value as an indicator of the level of iron stored $^{16}$ although this relationship is compromised by tissue damage particularly in the liver. ${ }^{17}$ In infants, postmortem, the remarkably high serum ferritin concentrations are also related to levels of stored iron (liver non-haem iron concentration). The high concentrations of serum ferritin found on immunoassay have been confirmed by the chemical determination of serum iron concentrations. In many cases serum iron concentrations were grossly in excess of the transferrin iron binding capacity of serum in live infants aged about six months, and the postmortem serum iron concentration was highly correlated with the serum ferritin concentration determined by immunoassay. Much of the iron is probably contributed by partial release of ferritin iron during the assay. ${ }^{18}$ In vivo plasma ferritin normally has a low iron conten $\mathrm{t}^{16}$ and provides only about $20 \%$ of blood ferritin, the remainder being supplied by blood cells. ${ }^{19}$ Even in completely lysed blood the ferritin concentration from the cellular elements will only increase the concentration found in normal serum by about four times. The grossly elevated plasma concentrations found postmortem must therefore be iron-rich ferritin derived from the tissues.

The extremely high serum ferritin concentrations described here appear to be characteristic of age rather than SIDS, but with the SIDS cases showing the highest concentrations. However, we were able to study only a few control cases up to one year of age and the 95\% CIs overlap.

In life there are two conditions associated with ferritin concentrations in excess of $10000 \mu \mathrm{g} / \mathrm{l}$ : necrosis of the liver ${ }^{17}$ and active erythrophagocytosis. ${ }^{20}$ Autolysis occurs postmortem. Active erythrophagocytosis also occurs in infants aged from one to six months. Particularly high concentrations of stored iron may be found in cells of the reticuloendothelial system at this age ${ }^{21}$ because of the high rate of haemoglobin breakdown and the relatively low rates of synthesis. ${ }^{2}$ Iron concentrations in phagocytic cells in the first weeks of life are higher than at any other time and may reach concentrations usually associated with haemochromatosis in adults. ${ }^{21}$ It is these high concentrations of tissue iron (and ferritin) which cause the postmortem release of ferritin into the blood in infants, but endothelial cells lining vessel walls are also capable of producing high concentrations of ferritin ${ }^{22}$ and may contribute directly to ferritin release. Ferritin concentrations in serum, like LDH and some other enzyme activities, ${ }^{23}$ increase rapidly after death so the lack of correlation between the blood ferritin concentration and the time of sampling after death was surprising. In some cases the ferritin concentrations were high at the time of death but in others the time of death could not always be established precisely, and the increase may have been completed already. Another cause of high ferritin concentrations may be the trauma caused by attempts at resuscitation. In the Nottingham series attempts to resuscitate in the ambulance or in hospital were recorded but these cases did not have higher concentrations than found in those where resuscitation was not attempted.

We have recently completed a study of ferritin concentrations in blood spots collected on "Guthrie cards" during the first week of life to determine whether infants who subsequently die of SIDS have higher tissue iron stores at birth (Raha-Chowdhury et al, submitted for publication). We have found no evidence of gross elevation of blood ferritin concentrations at birth in infants who subsequently died of SIDS. We have previously discussed ways in which excess iron may be acquired after birth ${ }^{3}$ but changes in tissue iron concentrations as a result of supplementation or administration of iron containing medicines are likely to be small.

By definition, there is no adequate explanation for SIDS at postmortem, suggesting an overwhelming toxic or metabolic disturbance as the cause of death. It is conceivable that oxidative cell damage may be the final biochemical event and the role of iron as an enhancer of free radical damage is well established. ${ }^{24}$ If oxidative cell damage is found to be implicated in the aetiology of SIDS then high tissue iron concentrations may be an important factor. The extraordinary ferritin concentrations found in blood postmortem are a reflection of these high tissue iron concentrations. This work has been supported by The Foundation for the Study
of Infant Deaths. We are most grateful to Drs S P Ward and A of Infant Deaths. We are most grateful to Drs S P Ward and A Jacobs (New Cross Hospital, Wolverhampton), Dr J W Keeling (Royal Hospital for Sick Children, Edinburgh), Dr V Suare (Stafford), Dr T P Rollason (Birmingham Maternity Hospital), and Dr G M Vujanic (Department of Pathology, University of Wales College of Medicine, Cardiff) for providing postmortem samples.

1 Gibson AAM. Current epidemiology of SIDS. $f$ Clin Pathol 1992;45:7-10.

2 Oski FA. The erythrocyte and its disorders. In: Nathan DG, Oski RA, eds Hematology of infancy and childhood. Vol. 1 . 4th edn. Philadelphia: WB Saunders, 1993:18-43.

3 Moore CA, Raha-Chowdhury R, Fagan DG, Worwood M. Liver iron concentrations in the Sudden Infant Death Syndrome. Arch Dis Child 1994;70:295-8.

4 Moore A, Worwood M. Iron and the Sudden Infant Death Syndrome. $B M \mathcal{F}$ 1989;298:1248.

5 Beckwith JB. Observations on the Pathological Anatomy of 
the Sudden Infant Death Syndrome. In: Bergman AB, Beckwith JB, Ray CG. Sudden infant death syndrome. Proceedings of the Second International Conference on the Causes of Sudden death in infants. Seattle: University of Washington, 1970:83-107.

6 Torrance JD, Bothwell TH. Tissue iron stores. In: Cook JD, ed. Methods in hematology. Vol 1. New York: Churchill

7 Worwood M, Thorpe SJ, Heath A, Flowers CH, Cook JD. Stable lyophilised reagents for the serum ferritin assay. Clin Lab Haematol 1991;13:297-305.

8 Jones BM, Worwood M. An immunoradiometric assay for the acidic ferritin of human heart: application to human tissues, cells and serum. Clin Chim Acta 1978;85:81-8.

9 Elliott BA, Wilkinson JH. Serum alpha-hydroxybutyric dehydrogenase in mycocardial infarction and liver disease. Lancet 1961;i:698-9.

10 Worwood M, Darke C. Serum ferritin, blood donation, iron stores and haemochromatosis. Transfusion Med 1993;3: 21-8.

11 Worwood M. Serum Ferritin. In: Jacobs A, Worwood M, eds. Iron in biochemistry and medicine II. London: Academic eds. Iron in biochemistry and medicine II. London: Academic

12 Saarinen UM, Siimes MA. Developmental changes in serum iron, total iron-binding capacity, and transferrin saturation in infancy. F Pediatr 1977;91:875-7.

13 Wagstaff $M$, Worwood $M$, Jacobs A. Iron and isoferritins in iron overload. Clin Sci 1982;62:529-40.

14 Meera Khan P. Enzyme electrophoresis on cellulose acetate gel: zymogram patterns in man-mouse amd man-Chinese hamster somatic cell hybrids. Arch Biochem Biophys 1971; 145:470-83.

15 Wilkinson $\mathrm{JH}$. The principles and practice of diagnostic enzymology. London: Edward Arnold, 1976.

16 Worwood M. Serum ferritin. Clin Sci 1986;70:215-20.

17 Prieto J, Barry M, Sherlock S. Serum ferritin in patients with iron overload and with acute and chronic liver diseases. iron overload and with acute and

18 Iron Panel of the International Committee for Standardization in Haematology. Revised recommendations for the measurements of the serum iron in blood. $\mathrm{Br} f$ Haematol 1990;75:615-16.

19 Worwood M. Serum Ferritin. Crit Rev Clin Lab Sci 1979; 10:171-204.

20 Esumi N, Ikushima S, Hibi S, Todo S, Imashuku S. High serum ferritin level as a marker of malignant histiocytosis and virus-associated hemophyagocytic syndrome. Cancer 1988;61:2071-6.

21 Seip M, Halvorsen S. Erythrocyte production and iron stores in premature infants during the first months of life. Acta Paediatr 1956;45:600-17.

22 Balla G, Jacob HS, Balla J, Rosenberg M, Nath K, Apple $\mathrm{F}$, et al. Ferritin-A cytoprotective antioxidant strategem of endothelium. F Biol Chem 1992;267:18148-53.

23 Enticknap JB. Biochemical changes in cadaver sera in fatal acute heart attacks. f Forensic Med 1960;7:135-46.

24 Halliwell B, Gutteridge JMC. Free radicals in biology and medicine. Oxford: Clarendon Press, 1989. 